\title{
Determining the Factors Affecting Capital Structure Decisions of Real Sector Companies Operating in ISE
}

\author{
Bengü Vuran ${ }^{1}$, Nihat Taş ${ }^{2} \&$ Burcu Adiloğlu ${ }^{3}$ \\ ${ }^{1}$ Business Administration Faculty, Finance Department, Istanbul University, Istanbul, Turkey \\ ${ }^{2}$ Business Administration Faculty, Quantitative Sciences Department, Istanbul University, Istanbul, Turkey \\ ${ }^{3}$ Business Administration Faculty, Accounting Department, Istanbul University, Istanbul, Turkey \\ Correspondence: Bengü Vuran, Business Administration Faculty, Finance Department, Istanbul University, \\ Istanbul, Turkey. E-mail: benguv@istanbul.edu.tr
}

Received: May 8, 2017

Accepted: June 22, 2017

Online Published: July 5, 2017

doi:10.5539/ijef.v9n8p25

URL: https://doi.org/10.5539/ijef.v9n8p25

This work was supported by Scientific Research Projects Coordination Unit of Istanbul University. Project number was 28631.

\begin{abstract}
Corporate capital structure remains a controversial issue in modern corporate finance. Since the seminal work by Modigliani and Miller (1958), a plethora of research has been undertaken in attempting to identify the determinants of capital structure. This paper analyzes the capital structure determinants of manufacturing, merchandising and service firms operating in Istanbul Stock Exchange (ISE) during the period from 2010 to 2013 comprising of 218 companies. This study addresses the following questions: Are the capital structure determinants of three types of firms in ISE driven by different factors? To answer this question, panel data methodology is applied to the sample of firms for the period from 2010 to 2013 . The results show that the manufacturing and merchandising firms exhibit similarities in their capital structure choices. For those firms, size and firm growth are positively related to leverage, whereas profitability have a negative relationship with their debt to assets ratio. For service firms, size and non-debt tax shield have significant positive impact on leverage but profitability negatively related to leverage. These findings provide evidence in favour of trade off theory and pecking order theory.
\end{abstract}

Keywords: capital structure, manufacturing firms, merchandising firms, service firms, ISE, panel data

\section{Introduction}

Capital structure is a crucial subject of corporate finance. Capital structure is essential for survival, growth and performance of a firm. Emprical studies show that capital structure and the factors affecting it vary with different determinants. Harris and Raviv (1991) noted that firms in a given industry will have similar leverage ratios while leverage ratios vary across industries.

This study contributes to the capital structure literature on developing countries by investigating the capital structure determinants of three types of firms listed in Istanbul Stock Exchange in Turkey. It allows to investigate the similarities and differences between capital structure determinants of three kinds: manufacturing, merchandising and service firms. Existing literature on capital structure of Turkish companies has not investigated this issue so far. Hence, this study is new in the context of capital structure research on Turkey as a developing economy.

This paper is organized as follows: Section two introduces the literature, section three describes the data and the methodology used and section four provides the emprical results of the study. Finally, the section five draws conclusion and discussion of results.

\section{Literature Review}

The first theory of capital structure is established by Modigliani and Miller addressing that the value of a firm is unaffected by how that firm is financed. Their 'capital structure irrelevance' proposition in relation to the value of firms operating in perfect markets derived from theoretical entity to form the basis of modern corporate 
finance theory.

Myers and Majluf (1984) explain the effects of the information asymmetries between insiders and outsiders of company. According to theory, companies follow a preferential order of financing sources and that before seeking debts, they would use internal funds.

Groth and Anderson (1997) suggest that aside from deciding on a target capital structure, a firm must manage its own capital structure. Imperfections in capital markets, taxes, and other practical factors influence the management of capital structure.

Most of the empirical evidence on capital structure comes from studies of the determinants of corporate debt ratios. Titman and Wessels (1988), Rajanand Zingales (1995), Graham (1996) and studies of issuing firms' debt vs. equity financing choice, Marsh (1982), Horakimian et al. (2003) successfully identify firm characteristics such as size, R\&D intensity, market-to-book ratio of assets, stock returns, asset tangibility, profitability and the marginal tax rate as important determinants of corporate financing choices.

Harris and Raviv (1991) conclude that it is necessary for empirical research to be directed to test determinants of capital structure in various contexts. Motivated by their conclusion, this study investigate the determinants of capital structure in the quite different context of Egypt. Bradley et al. (1984) also find that the debt ratio is inversely related to the cost of financial distress which includes bankruptcy costs and agency costs of debt.

Bauer (2004) examines the capital structure of listed companies in Visegrad countries (Czech Republic, Hungary, Poland and Slovak Republic). In his study, six potential determinants of capital structure are analyzed: size, profitability, tangibility, growth opportunities, non-debt tax shields and volatility. According to the results, leverage of a company is positively correlated with size and negatively correlated with profitability, tangibility and non-debt tax shields. There is a negative relationship between leverage measured in market value and growth opportunities.

A higher level of leverage is considered as high risk. In particular, firms rely on high leverage for future development. Rajan and Zingales (1995) indicate that the choice of leverage depends on the purpose of the analysis. Previous studies reveal that there are different approaches to measure leverage; including total liabilities to total assets, debt to equity and total long-term liabilities to total assets. In empirical studies of the determinants of capital structure, leverage is expressed either in book or market value terms.

Huang and Song (2002), Booth et al. (2001), Titman and Wessels (1988), Friend and Lang (1988), Kester (1986), and Rajan and Zingales (1995) conduct studies for G7 countries except for Germany and observe a negative relationship between leverage and profitability (profitability is proxied by return on assets (defined as earnings before interest and taxes divided by total assets)).

Voulgaris et al. (2007) investigate the determinants of capital structure of Greek manufacturing firms and formulate some policy implications that may improve the financial performance of the sector. Their study applies panel data of two random samples, one for small and medium sized enterprises (SMEs) and another for large sized enterprises (LSEs). The findings show that profitability is a major determinant of capital structure for both size groups. However, efficient asset management and asset growth are found essential for the debt structure of LSEs as opposed to efficiency of current assets, size, sales growth and high fixed assets (no comma here) which are found to affect the credibility of SMEs.

Daskalakis and Psillaki (2008) analyze the capital structure determinants for SMEs of Greece and France using panel data methods. They find that there are some similarities but also some differences in the behavior of the SMEs in the two countries, judged by the signs and magnitude of the coefficients of the capital structure determinants. There is a positive relationship between size and leverage in both countries. Larger firms seem to rely more on debt than smaller firms. Asset structure and profitability are negatively related with leverage. This negative relationship between profitability and leverage is consistent with the pecking order pattern of financing.

Much of the empirical research on the determinants is directed largely towards companies in developed countries. However, there has been relatively little research done to this date on companies listed in countries experiencing transition from a planned to market economic system like China. Chen (2004) is the first to study determinants of firm-level capital structure in China using a balanced panel of 77 listed companies. Huang and Song (2006) use a data set, which contains the market and accounting data (no comma here) from more than 1000 Chinese listed companies from 1994 to 2000 to document the characteristics of these firms in terms of capital structure. They report that the leverage in Chinese firms increases with firm size, non-debt tax shields and fixed assets, and decreases with profitability and correlates with industries.

Deari and Deari (2009) analyze factors influencing leverage of two groups of companies. The first group consists 
of 32 Macedonian non-financial companies listed on Macedonian Stock Exchange through the period 2005 to 2007. The second group includes 30 Macedonian small and medium-sized businesses covering the same period. Leverage is used as the dependent variable and the independent variables are profitability, tangibility, size, growth rate and non-debt tax shield. It is found in the study that tangibilityis negatively associated with leverage for listed and unlisted companies where as growth is positively associated with leverage for both Macedonian listed and unlisted companies. Non-debt tax shield is negatively associated with leverage for listed companies, and positively for unlisted companies. While profitability is statistically significant for both groups, size is estimated to have positive impact on leverage, but is not significant for both listed and unlisted companies.

The determinants of capital structure in Turkey are examined by Acaravc1 (2015) by using panel data models. The study includes a random sample of 79 manufacturing firms listed in Istanbul Stock Exchange for the period of 1993 to 2010. In the analysis; profitability, growth opportunities, tangibility, size and non-debt tax shields are used as the firm-specific variables.Empirical results show significant relationship between growth opportunities, profitability, size, tangibility and leverage variables whereas an insignificant relation is observed between non-debt tax shields and the leverage. While the significance of growth opportunity supports the trade-off theory the significance of size, tangibility and profitability support the pecking order theory. And the study reveals that profitability and growth opportunity variables have more significant effects on leverage than the other variables.

Another study which tries to identify the determinants of capital structure of firms belongs to Groen (2016). The dataset includes 186 listed Dutch firms for the period from 2010 to 2013. Profitability, non-debt tax shields and business risk are found to be negatively related to leverage indicating that the capital structure of Dutch firms show some attributes of both pecking order and trade-off theory.

Matias and Serrasqueiro (2017) study the relationship between growth, profitability,size, asset structure, age (remove the second and)!! and debt for 11,016 Small and Medium-Sized Enterprises (SMEs) in Portugal for the sample period from 2007 to 2011. The findings of the study demonstrate that those variables are significantly associated with capital structures ofPortuguese SMEs.

Farrukh and Asad (2017) show that liquidity and profitability, non-debt tax shield and growth are significantly linked with leverage but tangibility of assets and firm size are not. Their study utilizes panel pooled regression model on a sample period from 2012 to 2016 for businesses enrolled on the Karachi Stock Exchange.

\section{Data and Methodology}

In this study, the determinants of capital structure of ISE companies are investigated by using panel data analysis, employing a sample of 218 Turkish firms by classifying them into three groups namely manufacturing, merchandising and service. The data consist of 161 manufacturing, 32 service and 25 merchandising firms and spans from 2010 to 2013. Panel data analysis is performed for each group.

The data are obtained from finnet database (www.finnet.gen.tr). Table 1 displays the variables used in the analysis.

Table 1. Variables of the analysis

\begin{tabular}{lll}
\hline Variable & Code & Definition \\
\hline Leverage & $\mathrm{Y}:$ & Total Debt / Total Assets \\
Size & $\mathrm{X} 1$ & Log Total Assets \\
& $\mathrm{X} 2$ & Log Sales \\
Tangibility & $\mathrm{X} 3$ & Tangible Assets / Total Assets \\
Growth Opportunities & $\mathrm{X} 4$ & Price / Earning Ratio \\
Non-Debt Tax Shield & $\mathrm{X} 5$ & Depreciation Expense / Total Assets \\
Profitability & $\mathrm{X} 6$ & Net Profit After Taxes / Total Assets \\
& $\mathrm{X} 7$ & EBIT / Total Assets \\
Firm Growth & $\mathrm{X} 8$ & gsales \\
& $\mathrm{X} 9$ & gtotal assets \\
\hline
\end{tabular}

The panel static models analyzed in this paper are pooled effects, fixed effects and random effects and they are shown below:

$$
y_{i t}=\mu+\sum_{k=1}^{p} \beta_{k} x_{k i t}+\varepsilon_{i t}
$$

(pooled model) 


$$
\begin{gathered}
y_{i t}=\left(\mu+\alpha_{i}\right)+\sum_{k=1}^{p} \beta_{k} x_{k i t}+\varepsilon_{i t} \\
y_{i t}=\mu+\sum_{k=1}^{p} \beta_{k} x_{k i t}+\left(\alpha_{i}+\varepsilon_{i t}\right)
\end{gathered}
$$

(fixed effects)

(random effects)

Where $y_{i t}$ is the dependent variable showing the leverage of the firm $\mathrm{i}$ to the period $\mathrm{t} . \mu$ is the intercept of the pooled equation showing the mean firm specific effects for the fixed and the random effects model. $\beta_{k}$ is the slope coefficient for the $x_{k}$ independent variable. The error terms are represented by $\varepsilon_{i t}$ for the first two models and represented by $\left(a_{i}+\mathcal{E}_{i t}\right)$ for the third model.

Firm size is one of the major variables used in explaining the level of debt usage. According to trade-off model, larger firms are expected to use more debt since they have more stable and less volitile cash flows. They can borrow under better conditions and they can easily access credit markets as compared to smaller firms. So size is expected to have a positive effect on larger firm borrowing. As a proxy for firm size, both natural logarithm of total asset and sales variables are taken into consideration.

The level of tangible assets is considered as guarantee to its creditors. Therefore, the existence of tangible assets affects the level of debt. Manufacturing firms have higher level of fixed assets than non-manufacturing firms. This implies a greater need for sources of capital to finance those assets which in turn can be used as collateral on loans. Therefore tangible assets / total assets is used as a measure of tangibility. Firms with higher portion of tangible assets are more likely to belong to manufacturing sector because manufacturing companies rely on tangible assets when producing their goods. So this ratio is expected to be significant especially for manufacturing firms.

According to Myers (1977), firms with high future growth opportunities should use more equity financing, because a higher levered company is more likely to miss the opportunity of profitable investment. Therefore a negative relationship between growth opportunities and leverage is predicted.

There are conflicting theoretical predictions regarding profitibility on firm leverage. The trade-off theory says that profitable companies employ more debt since they are more likely to have a high tax burden and low bankruptcy risk. But the pecking order theory predicts a negative relationship between leverage and profitability since profitable companies do not need much external funding. As a proxy for profitability both net profit after taxes / total assets and earnings before interest and tax / total assets are selected in this study.

There are two variables measuring size, profitability and growth of the firms obtained for the analysis. It is needed to choose one of the variables and insert into models. To choose the appropriate one, both correlation matrix and model performance are examined. Then, $\mathrm{X}_{1}, \mathrm{X}_{6}$ and $\mathrm{X}_{8}$ variables are included into model for size, profitability and firm growth respectively.

\section{Results}

The test results of cross section heterogenity for the three groups (161 manufacturing, 32 service and 25 merchandising firms) are given in the Table 2 where the null hypothesis is given as "There is no firm specific effects in the model (the pooled panel regression can be used)". Null hypothesis is rejected for each group implying that firm specific effects should be modelled since the pooled regression estimators are biased (Gujarati, 2004, p. 643).

Table 2. F test results for cross section heterogenity (fixed effects)

\begin{tabular}{llll}
\cline { 2 - 3 } & & F Statistics & p-value \\
\cline { 2 - 4 } & Manufacturing & $F_{160,459}=17.16$ & 0.0000 \\
& Service & $F_{31: 88}=13.06$ & 0.0000 \\
& Merchandising & $F_{24,67}=16.93$ & 0.0000 \\
\cline { 2 - 3 } Note. $H_{0}: u_{i}=0$ & $(\forall i)$ & &
\end{tabular}

Under the null hypothesis of the variances of the firm specific effects are equal to zero, p-values obtained are 0.000 for each model tested by the Lagrange Multiplier test given in Table 3. According to these results, a panel model which has the firm specific effects should be formed (Hill et al., 2011, p. 554). 
Table 3. Lagrange multiplier test results for cross section heterogenity (Random effects)

\begin{tabular}{ccc} 
& LM Statistics & p-value \\
\cline { 2 - 3 } Manufacturing & $\chi_{1}^{2}=498.97$ & 0.0000 \\
Service & $\chi_{1}^{2}=94.25$ & 0.0000 \\
Merchandising & $\chi_{1}^{2}=88.89$ & 0.0000 \\
\cline { 2 - 2 } & $\sigma_{u}^{2}=0$ &
\end{tabular}

In Table 4, the null hypothesis of the standard deviations of the firm specific effects are equal to zero is tested by the Likelihood Ratio test. Results indicate that non-pooled specification of the firm specific effects are considered (Baltagi, 2011, p. 319).

Table 4. Likelihood Ratio test results for cross section heterogenity (Random effects)

\begin{tabular}{lcc}
\hline & LR Statistics & p-value \\
\hline Manufacturing & $\chi_{1}^{2}=523.68$ & 0.0000 \\
Service & $\chi_{1}^{2}=91.84$ & 0.0000 \\
Merchandising & $\chi_{1}^{2}=85.08$ & 0.0000 \\
\hline
\end{tabular}

Note. $H_{0}: \sigma_{u}=0$

Hausman specification test is developed to identify whether the fixed or the random effects model is appropriate when the model has non-constant firm specific effects (Arellano, 2003, p. 40). Results shown in Table 5 display that the model for the manufacturing firms has firm specific fixed effects where service and merchandising firms have firm specific random effects (Wooldridge, 2012, p. 496).

Table 5. Hausman specification test results

\begin{tabular}{|c|c|c|}
\hline & Hausman $\chi^{2}$ Statistics & p-value \\
\hline Manufacturing & $\chi_{5}^{2}=116.62$ & 0.0000 \\
\hline Service & $\chi_{1}^{2}=3.15$ & 0.6765 \\
\hline Merchandising & $\chi_{4}^{2}=5.12$ & 0.2751 \\
\hline
\end{tabular}

The most important assumptions of the fixed effects estimator are homoscedasticity, no serial correlation and no contemporaneous correlation. Testing for homoscedasticity is performed by using modified Wald test for the null hypothesis of homoscedasticity against the heteroscedastic alternative. Testing for serial correlation is performed by using Wooldridge's serial correlation test. Results of these hypotheses are given below in Table 6 and Table 7 respectively. All three Wald test statistics are found as significant meaning that models have heteroscedastic error terms. Wooldridge's serial correlation test statistics indicate serial correlation in the error terms of the models of the manufacturing and service firms whereas no serial correlation exist for the merchandising firms.

To test the absence of the contemporenaous correlation assumption, Breusch-Pagan Lagrange Multiplier test, Pesaran CD test, Friedman's R test and Frees' Q test can be performed. (Tatoğlu, 2012, p. 215) Those tests can not be applied since data considered are unbalanced and have no enough observations to get test statistics. Models presented in the Table 8 take those model violations into account and use robust standard errors.

Table 6. Modified Wald test results for homoscedasticity

\begin{tabular}{lll} 
& Modified Wald $\chi^{2}$ Statistics & p-value \\
\hline Manufacturing & $\chi_{32}^{2}=1.9 * 10^{32}$ & 0.0000 \\
Service & $\chi_{32}^{2}=2.2 * 10^{29}$ & 0.0000 \\
Merchandising & $\chi_{25}^{2}=89228.34$ & 0.0000 \\
\hline
\end{tabular}

Note. $H_{0}: \sigma_{i}^{2}=\sigma^{2} \quad(\forall i)$ 
Table 7. Wooldridge's first order autocorrelation test results

\begin{tabular}{lll}
\hline & Wooldridge F Statistics & p-value \\
\hline Manufacturing & $F_{1 ; 155}=31.46$ & 0.0000 \\
Service & $F_{1 ; 30}=20.60$ & 0.0001 \\
Merchandising & $F_{1 ; 24}=2.02$ & 0.1683 \\
\hline
\end{tabular}

Note. $H_{0}$ : No first order correlation.

Estimated models and estimations of coefficients are presented in the Table 8. Coefficients of $x_{1}, x_{6}$, and $x_{8}$ variables are found significant at the 5\%,1\% and 5\% significance level for the manufacturing and $1 \%, 1 \%$ and $1 \%$ significance level for the merchandising firms while $x_{1}, x_{5}$ and $x_{6}$ variables are found significant at the $1 \%$ level for the service firms.

Table 8. Model results for the subgroups defined

\begin{tabular}{lccc}
\hline Variable & $\begin{array}{c}\text { Manufacturing } \\
\text { FE1_DK_E }\end{array}$ & $\begin{array}{c}\text { Service } \\
\text { RE2 }\end{array}$ & $\begin{array}{c}\text { Merchandising } \\
\text { RE3 }\end{array}$ \\
\hline$x_{1}$ & $0.2421^{*}$ & $0.0857^{* * *}$ & $0.1134^{* *}$ \\
se & 0.0549 & 0.0220 & 0.0324 \\
$p$-value & 0.0216 & 0.000 & 0.000 \\
\hline$x_{5}$ & - & $1.4483 * *$ & - \\
se & - & 0.3893 & - \\
$p$-value & - & 0.000 & $-0.3470^{* *}$ \\
\hline$x_{6}$ & $-0.3844^{* *}$ & $-0.6639^{* *}$ & 0.1187 \\
se & 0.0241 & 0.0836 & 0.003 \\
$p$-value & 0.0005 & 0.000 & $0.0015^{* *}$ \\
\hline$x_{8}$ & $0.0194^{*}$ & - & 0.2777 \\
se & 0.006 & - & 0.001 \\
$p$-value & 0.0482 & - & $-0.8015^{* *}$ \\
const & $-1.8051^{*}$ & $-0.4719 *$ & 0.2777 \\
se & 0.4588 & 0.1912 & 0.004 \\
\hline -value & 0.0292 & 0.014 & Wald $\chi_{3}^{2}=27.22$ \\
\hline Model Test & $F_{3 ; 3}=432.70$ & Wald $\chi_{3}^{2}=133.73$ & 0.0000 \\
$p$-value & 0.0002 & 0.0000 & \\
\hline
\end{tabular}

Note. $* *$ and $*$ symbols show significant results at the $1 \%$ and $5 \%$ levels respectively.

\section{Conclusion}

Capital structure is a crucial aspect in performance of firms. This study analyzes the determinants of capital structure decisions of Turkish listed companies utilizing panel data of three groups namely manufacturing, merchandising and service firms. The financial data are collected for the period of 2010 to 2013 for three distinct samples and panel data method is employed.

Emprical results show that firm size (measured as total assets) is statistically significant in all three models and has a positive effect on leverage. The fact that size is positively related with leverage suggests that larger firms have better access to bank financing because of their higher credibility and use of colleteral. The positive impact of size on capital structure concurs with trade off theory which states larger firms are expected to have a higher debt capacity and are able to be more levered. This result is consistent with many studies in literature (Bauer, 2004; Chen, 2004; Huang \& Song, 2002; Daskalakis \& Psillaki, 2008; Groen, 2016).

Profitability (measured as Net Profit After Taxes / Total Assets) is found significant but negative effect on capital structure for three groups. The negative effect is explained by pecking order theory which states profitable companies do not need to depend so much on external funding. Instead, they prefer to finance with internal funds accumulated from past profits. This result is also supported with many findings in literature (Titman \& Wessels, 1988; Friend \& Lang, 1988; Kester, 1986; Rajan \& Zingales, 1995; Bauer, 2004; Huang \& Song, 2002; Booth et al., 2001; Daskalakis \& Psillaki, 2008; and Groen, 2016). 
Firm growth (measured as growth in sales) is found statistically significant determinant of capital structure for manufacturing and merchandising firms. This result is also consistent with Myers' agency cost and pecking order theory. Growth pushes fast growing firms into seeking external financing and they maintain higher debt level in their capital structure. This also concurs with findings of other studies (Voulgaris et al., 2007; Deari \& Deari, 2009; Farrukh \& Asad, 2017).

Non-debt tax shield (annual depreciation expense to total assets) relates positively with leverage and it is only statistically significant for service firms meaning that in case of heavy investment in tangible assets, the service firms tend to use debt financing.

These findings suggest that there exists no difference in the determinants of capital structure among manufacturing and merchandising firms in Turkey. Size, profitability and firm growth are the determinants which affects the capital structure decisions of those firms. Besides the size and profitability variables, the non-debt tax shield variable shows a significant and positive relationship for service firms.

The most remarkable conclusion in our study is that there seems to be a similar behaviour in determination of capital sturucture for manufacturing and merchandising firms, as the analysis provided the same signs in the relationship between each regressor and dependent variable.

It will also be of interest to explore further in this issue by comparing the capital structure determinants for different sectors across different countries.

\section{References}

Acaravc1, S. K. (2015). The Determinants of Capital Structure: Evidence from the Turkish Manufacturing Sector. International Journal of Economics and Financial Issues, 5(1), 158-171.

Arellano, M. (2003). Panel Data Econometrics. New York: Oxford University Press. https://doi.org/10.1093/0199245282.001.0001

Baltagi, B. H. (2011). Econometrics (5th ed.). Springer, USA. https://doi.org/10.1007/978-3-642-20059-5

Bauer, P. (2004). Capital structure of listed companies in Visegrad Countries. Prague Economic Papers, 2, 159-175. https://doi.org/10.18267/j.pep.237

Booth, L., Aivazian, V., Demirguc-Kunt, A., \& Maksimovic, V. (2001). Capital Structure in Developing Countries. Journal of Finance, 56, 87-130. https://doi.org/10.1111/0022-1082.00320

Bradley, M., Jarrell, G. A., \& Kim, E. H. (1984). On the existence of an optimal capital structure. Journal of Finance, 39(3), 857-78. https://doi.org/10.1111/j.1540-6261.1984.tb03680.x

Chen, J. J. (2004). Determinants of capital structure of Chinese-listed companies. Journal of Business Research, 57(12), 1341-1351. https://doi.org/10.1016/S0148-2963(03)00070-5

Daskalakis, N., \& Psillaki, M. (2008). Do country or firm factors explain capital structure? Evidence from SMEs in France and Greece. Applied Financial Economics, 18(2), 87-97. http://dx.doi.org/10.1080/09603100601018864

Deari, F., \& Deari, M. (2009). The Determinants of Capital Structure: Evidence From Macedonian Listed and Unlisted Companies. Analele Stiintifice ale Universitatii "Alexandru Ioan Cuza" din Iasi Journal, 56, 91-102.

Farrukh, W., \& Asad, M. (2017). The Determinants of Capital Structure: A Study on Cement Sector of Pakistan. International Journal of Management Sciences and Business Research, 6(2), 16-26.

Friend, I., \& Lang, L. (1988). An Empirical Test of the Impact of Managerial Self-interest on Corporate Capital Structure. Journal of Finance, 43, 271-281. https://doi.org/10.1111/j.1540-6261.1988.tb03938.x

Graham, J. R. (1996). Proxies for The Corporate Marginal Tax Rate. Journal of Financial Economics, 42(2), 187-221. https://doi.org/10.1016/0304-405X(96)00879-3

Groen, J. B. (2016). Capital structure determinants: An inter-industry analysis for Dutch firms (Bachelor Essay). University of Twente Student Theses. Retrieved from http://purl.utwente.nl/essays/70034

Groth, J. C., \& Anderson, R. C. (1997). Capital structure: Perspectives for managers. Management Decision, 35(7), 552-561. https://doi.org/10.1108/00251749710170529

Gujarati, D. N. (2004). Basic Econometrics (4th ed.). USA: McGraw Hill.

Harris, M., \& Raviv, A. (1991). The theory of capital structure. Journal of Finance, 46, 297-355. 
https://doi.org/10.1111/j.1540-6261.1991.tb03753.x

Hill, R. C., Griffiths, W. E., \& Lim, G. C. (2011). Principles of Econometrics (4th ed.). Wiley, USA.

Horakimian, A., Horakimian, G., \& Tehranian, H. (2003). Determinants of Target Capital Structure: The Case of Dual Debt and Equity Issues. Seminar presented at Baruch College.

Huang, G., \& Song, F. M. (2006). The determinants of capital structure: Evidence from China. China Economic Review, 17(1), 14-36. https://doi.org/10.1016/j.chieco.2005.02.007

Huang, S. G., \& Song, F. M. (2002). The Determinants of Capital Structure: Evidence from China. Hong Kong Institute of Economics and Business Strategy, Working Paper No. 1042. https://doi.org/10.2139/ssrn.320088

Kester, C. W. (1986, Spring). Capital and Ownership Structure: A Comparison of United States and Japanese Manufacturing Corporations. Financial Management, 15(1), 5-16. https://doi.org/10.2307/3665273

Marsh, P. (1982). The Choice between Equity and Debt: An Empirical Study. Journal of Finance, 37, 121-144. https://doi.org/10.1111/j.1540-6261.1982.tb01099.x

Matias, F., \& Serrasqueiro, Z. (2017, April). Are there reliable determinant factors of capital structure decisions? Empirical study of SMEs in different regions of Portugal. Research in International Business and Finance, 40, 19-33. http://dx.doi.org/10.1016/j.ribaf.2016.09.014

Modigliani, F., \& Miller, M. (1958). The Cost of Capital, Corporation Finance, and the Theory of Investment. American Economic Review, 48, 261-297.

Myers, S. C. (1977). Determinants of Corporate Borrowing. Journal of Financial Economics, 5, 147-175. https://doi.org/10.1016/0304-405X(77)90015-0

Myers, S. C., \& Majluf, N. S. (1984). Corporate Financing and Investment Decisions When Firms Have Information Investors Do Not Have. Journal of Financial Economics, 13, 187-222. https://doi.org/10.1016/0304-405X(84)90023-0

Rajan, R. G., \& Zingales, L. (1995). What Do We Know about Capital Structure? Some Evidence from International Data. Journal of Finance, 50, 1421-1460. https://doi.org/10.1111/j.1540-6261.1995.tb05184.x

Tatoğlu, F. Y. (2012). Panel Veri Ekonometrisi. Beta, İstanbul.

Titman, S., \& Wessels, R. (1988). The Determinants of Capital Structure Choice. Journal of Finance, 43, 1-19. https://doi.org/10.1111/j.1540-6261.1988.tb02585.x

Voulgaris, F., Asteriou, D., \& Agiomirgianakis, G. (2007). Size and Determinants of Capital Structure in the Greek Manufacturing Sector. International Review of Applied Economics, 18(2), 247-262. http://dx.doi.org/10.1080/0269217042000186714

Wooldridge, J. M. (2012). Introductory Econometrics A Modern Approach (5th ed.) South-Western Cengage Learning, USA.

\section{Copyrights}

Copyright for this article is retained by the author(s), with first publication rights granted to the journal.

This is an open-access article distributed under the terms and conditions of the Creative Commons Attribution license (http://creativecommons.org/licenses/by/4.0/). 